Agro-Science Journal of Tropical Agriculture, Food, Environment and Extension Volume 13 Number 2 May 2014 pp. $37 \quad-42$

ISSNIII9-7455

\title{
EVALUATION OF CASSAVA-BASED SYSTEMS FOR ADAPTATION TO CLIMATIC VARIATIONS IN EASTERN NIGERIA
}

\author{
${ }^{1 *}$ Asadu, C.L.A., A.G.O. Dixon ${ }^{2}$ and S. C. Eze ${ }^{3}$ \\ ${ }^{1}$ Department of Soil Science, University of Nigeria, Nsukka, Nigeria \\ ${ }^{2}$ International Institute of Tropical Agriculture (IITA), Ibadan, Nigeria \\ ${ }^{3}$ Department of Crop Science, University of Nigeria, Nsukka, Nigeria \\ *E-mail: charlesasadu@yahoo.com (Corresponding author);
}

\begin{abstract}
Three cassava-based systems viz: solely cassava $(\mathrm{SC})$, cassava + pigeon pea $(C+P)$ and Cassava + pigeon pea + maize were evaluated for five years using cassava root, shoot yields and their ratio as the index of adaptation to climatic variations. The study was carried out in two locations, one within the University of Nigeria, Nsukka (UNN) farm near the Meteorological station and the other about one $\mathrm{km}$ off the Campus and in a newly cleared forestland. The experimental design was a randomized complete block design (RCBD) replicated three times in each location. Three climatic elements (rainfall, temperature and relative humidity) were obtained from the Meteorological station each year. The yields were significantly $(p \leq 0.05)$ affected by location, year, and the cropping systems. Out of the three climatic variables the relative humidity accounted for about $60 \%$ variation in root yield and $56 \%$ in shoot yield. Their ratio was not significantly influenced. The highest average root yield $\left(15 \mathrm{t} \mathrm{ha} \mathrm{h}^{-1}\right)$ came from $\mathrm{C}+\mathrm{P}+\mathrm{M}$ plots at forestland location and the least $(2.2 \mathrm{t}$ $\left.\mathrm{ha}^{-1}\right)$ from $C+P$ plots at the UNN location. Thus, $C+P+M$ mixture was considered the most adapted to the area.
\end{abstract}

Keywords: Cassava, climate, cropping systems, Eastern Nigeria

\section{INTRODUCTION}

Cassava (Manihot esculenta Crantz) is the third most important source of calories in the tropics, after rice and maize and could become the raw material base for an array of processed products that will effectively contribute to agricultural transformation and economic growth in developing countries (FAO, 2008). Cassava is a food security crop and supplies more than $65 \%$ of the calorific energy needs of the people of sub-Saharan Africa including eastern Nigeria (Nweke et al., 2002). It is grown by over $90 \%$ of farmers in eastern Nigeria and over $70 \%$ grow it in various intercropping (polyculture) systems (IITA, 1984; Okorji, 1986; Asadu, 1997). The most popular crop grown with cassava in the region is maize (Zea mays). The current observations about significant variations in climatic elements in Nsukka, eastern Nigeria (Asadu, 2002) lends credence to the climate change being reported globally. The performance of any crop depends on its genetic make up; edaphic, climatic and cultural conditions under which it is grown (Asadu et al, 2002). The most critical elements of climate in crop production are rainfall, temperature and relative humidity. Though cassava is generally known to be a hardy crop, (growing where most other arable crops may not do well), its adaptation to variations in climatic elements needs to be understood. It has been referred to as a "survivor" crop able to thrive in the expected higher temperatures engendered by climate change (Alliance of Scientists, 2012). Climate affects soil nutrient availability to plants, disease and pest incidence (Asadu 2002 ), thus the overall performance of any crop is directly or indirectly related to climatic variables. It is often difficult to isolate these factors and determine their individual contributions to crop yield especially in crop mixtures. Most studies on intercropping had often dwelt on its advantages over sole cropping 
(Andrew, 1972; Okorji, 1986; Asadu, 1997; Kantor, 1999). Soil variables have been reported to account for up to $70 \%$ variations in cassava yield (Asadu et al 2002) but climatic elements were not considered. Thus, the objective of the study was to relate the performance of cassava in three cropping systems with changes in rainfall, temperature and relative humidity

\section{MATERIALS AND METHODS \\ Location of the study}

Nsukka is located by Lat. $06^{0} 52^{\prime} \mathrm{N}$, Long. $07^{0}$ 24 'E within the derived savanna zone of Eastern Nigerian. It is on an average elevation of $447 \mathrm{~m}$ above sea level. It has two seasons namely the rainy and the dry seasons. The former lasts from April to October with a short break (August Break) in the month of August. Average annual rainfall is about $1550 \mathrm{~mm}$ and more than $85 \%$ of this rain falls within the rainy season. The average minimum and maximum temperatures are about 22 and $30{ }^{\circ} \mathrm{C}$ respectively while the average relative humility is rarely below $60 \%$ (Asadu, 2002). The soil was formed from the residua of false-bedded sandstone and has been classified by Asadu et al. (2002) as Rhodic Kandustalf (Haplic Lixisol). The study was carried out in two locations; at the Department of Soil Science, University of Nigeria, Nsukka (UNN) farm that was under fallow for eight years prior to the study and at a virgin forestland cleared for the study.

\section{Experimental design, field sampling and data analysis}

The design was a randomized complete block design (RCBD) with two locations, and three cropping systems as treatment factors. The cropping systems were selected based on prior knowledge of the most common staple food crops grown by the local farmer. They included cassava + maize + pigeon pea $(\mathrm{C}+\mathrm{M}+\mathrm{P})$, cassava + pigeon pea $(\mathrm{C}+\mathrm{P})$ and sole cassava $(\mathrm{SC})$. The cropping systems were replicated three times in each location. The trials were established between May 15 and 18, each year from 1998 2002. Each crop was planted at a spacing of $1 \mathrm{~m}$ $\mathrm{x} 1 \mathrm{~m}$ on the ridges. The plot size was $5 \mathrm{~m} \mathrm{x} 8 \mathrm{~m}$.
Maize and pigeon pea were planted by the sides of the ridges in mixtures. However, two grains of maize and two seeds of pigeon pea were planted per hole as is done by the local farmers in the area. This population was maintained in both plots of the sole and crop mixtures. The ridges were made with local hoes.

Fresh root and shoot yields of cassava were taken from an area $20 \mathrm{~m}^{2}$ at the centre of the plots twelve months after planting, harvesting being in the years 1999, 2000, 20012002 and 2003. Rainfall, temperature and relative humidity data were obtained from the Faculty of Agriculture Meteorological station adjacent to the UNN location during the same period. Analysis of Variance (ANOVA) for the yield data was done using SAS (1985) window package. The contribution of climatic variables selected by stepwise multiple regression analysis to cassava root and shoot yield variations were evaluated by the magnitude of the partial coefficients of determination $\left(\mathrm{R}^{2}\right)$ following similar procedures adopted in earlier studies ( Majchrzak et al., 2001; Asadu et al., 2002).

\section{RESULTS AND DISCUSSION}

From Table 1, location, cropping system and year of cultivation effects were all highly significant on both the root and shoot yields of cassava. Their interaction effects were also significant on both parameters The year of cultivation and its interaction effect were not significant on root/shoot ratio (Table 1). The significant effect of year of cultivation and associated interaction effects are indications that climatic variables interacted with other factors to influence the cassava yield parameters. This is, however, not surprising because crop performance is generally determined by edaphic, climatic and cultural conditions apart from its genetic endowment (Asadu et al., 2002). The variation in climatic elements within the five years were in the order rainfall $(\mathrm{Cv}=12 \%)>$ temperature $(\mathrm{Cv}=9 \%)>$ relative humidity $(\mathrm{Cv}$ $=2 \%$ ) as against the long-term normal Cvs of $16 \%, 7 \%$ and $4 \%$ respectively (Asadu et al., 2008). 


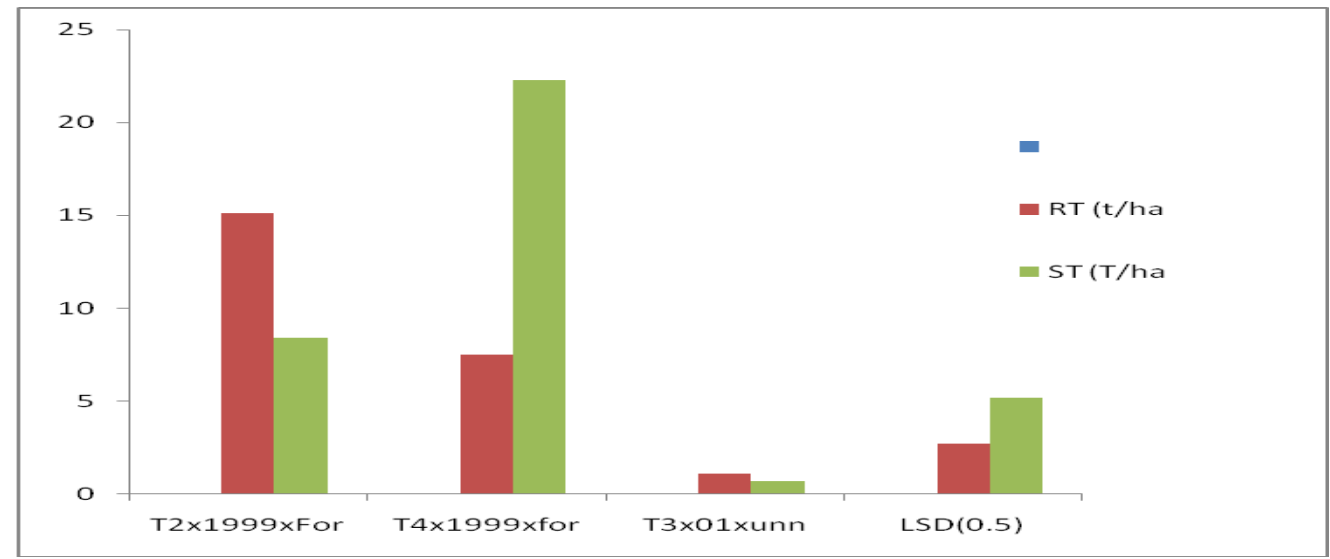

Fig.1: Years of highest and lowest root and shoot yields of cassava by location in eastern Nigeria

Table 1: ANOVA on Root, Shoot yields and their ratio from 1998 to 2003 in eastern Nigeria

\begin{tabular}{|c|c|c|c|}
\hline Source of variation & DF & F-value & Prob. Level \\
\hline \multicolumn{4}{|c|}{ Root Yield } \\
\hline Location (Loc) & 1 & 122.02 & $<0.001$ \\
\hline Treatment (Trt) & 2 & 5.12 & $<0.05$ \\
\hline Year (Yr) & 4 & 43.50 & $<0.001$ \\
\hline Loc $x$ Trt & 2 & 3.01 & $<0.05$ \\
\hline Trt $x$ Yr & 8 & 10.27 & $<0.001$ \\
\hline Loc $x$ Trt $x$ Yr & 12 & 5.02 & $<0.001$ \\
\hline \multicolumn{4}{|c|}{ Shoot Yield } \\
\hline Location (Loc) & 1 & 193.48 & $<0.001$ \\
\hline Treatment (Trt) & 2 & 3.83 & $<0.05$ \\
\hline Year $(Y \mathbf{r})$ & 4 & 16.29 & $<0.001$ \\
\hline Loc $x$ Trt & 2 & 8.44 & $<0.001$ \\
\hline Trt $x$ Yr & 8 & 0.87 & Ns \\
\hline Loc $x$ Trt $x$ Yr & 12 & 4.15 & $<0.001$ \\
\hline \multicolumn{4}{|c|}{ Root/Shoot Ratio } \\
\hline Location (Loc) & 1 & 38.40 & $<0.001$ \\
\hline Treatment (Trt) & 2 & 1.79 & Ns \\
\hline Year (Yr) & 4 & 0.68 & Ns \\
\hline Loc $x$ Trt & 2 & 11.05 & $<0.001$ \\
\hline Trt $x$ Yr & 8 & 1.65 & Ns \\
\hline Loc $x$ Trt $x$ Yr & 12 & 3.61 & $<0.001$ \\
\hline
\end{tabular}

Table 2: Mean interaction effects of cropping systems by year on root and shoot yields of cassava in eastern Nigeria

\begin{tabular}{lll}
\hline Cropping system x year & $\begin{array}{l}\text { Root yield } \\
\text { tha }^{-1} \text { ) }\end{array}$ & $\begin{array}{l}\text { Shoot yield } \\
\text { tha }^{-1} \text { ) }\end{array}$ \\
\hline Cassava + Maize +Pigeon pea (T1) x1999 & 15.1 & 15.6 \\
Cassava + Maize +Pigeon pea (T1) x2000 & 5.5 & 10.8 \\
Cassava + Maize +Pigeon pea (T1) x 2001 & 6.7 & 6.7 \\
Cassava + Maize +Pigeon pea (T1) x 2002 & 4.9 & 5.2 \\
Cassava + Maize +Pigeon pea (T1) x 2003 & 5.8 & 4.1 \\
Cassava + Pigeon pea (T3) x 1999 & 10.3 & 10.1 \\
Cassava + Pigeon pea (T3) x 2000 & 6.9 & 18.1 \\
Cassava + Pigeon pea (T3) x 2001 & 6.8 & 7.5 \\
Cassava + Pigeon pea (T3) x2002 & 5.6 & 4.4 \\
Cassava + Pigeon pea (T3) x 2003 & 7.8 & 11.3 \\
Cassava sole (T4) x 1999 & 10.2 & 24.8 \\
Cassava sole (T4) x 2000 & 5.6 & 13.6 \\
Cassava sole (T4) x 2001 & 6.9 & 8.7 \\
Cassava sole (T4) x 2002 & 7.8 & 5.2 \\
Cassava sole (T4) x 2003 & 7.6 & 10.2 \\
LSD(0.05) & 2.8 & 7.4 \\
\hline
\end{tabular}


For each cropping system, the root yields in 1999 (the first harvest) were the highest over the five years (Table 2). Again among the highest root yields, the value obtained from $\mathrm{C}+\mathrm{M}+\mathrm{P}$ $\left(15.1 \mathrm{t} \mathrm{ha}^{-1}\right)$ was significantly $(\mathrm{p}<0.05)$ higher than those from both $\mathrm{C}+\mathrm{P}\left(10.3 \mathrm{tha}^{-1}\right)$ and sole cassava plots $\left(10.2 \mathrm{t} \mathrm{ha}^{-1}\right)$. The root yields drastically decreased by almost $50 \%$ in subsequent years. The lower root yields from sole cassava plots could be due to excessive vegetative growth $\left(\approx 25 \mathrm{t} \mathrm{ha}^{-1}\right)$. This is because the UNN location was under fallow for eight years prior to the establishment of the trial while that of the forestland appeared to be over 100 years since all the farmers as well as their predecessors who own the land could not recall when there was any cultivation there. They termed it a "virgin forest" implying that it had never been put into cultivation before. Thus, the three crops shared the excess nutrients in the case of cassava + maize+ Pigeon pea $(C+M$ $+\mathrm{P})$ mixture and cassava translated this into high root yield and less vegetative growth $\quad(\approx 16$ $\left.\mathrm{t} \mathrm{ha}^{-1}\right)$. Most crops including cassava are known to be involved in luxury uptake of nutrients in situations of excess availability resulting in excessive vegetative growth. Cassava has long been known to give better root yield in soils of medium fertility (Howeler, 1996).

An analysis by Asadu (1997) attributed the variations in cassava root yields to variations in rainfall pattern of the area but the analysis did not involve other climatic elements especially temperature and relative humidity $(\mathrm{RH})$. The present analysis shows that the most important climatic element affecting both cassava root and shoot yields is RH. The result of the analysis shows that $\mathrm{RH}$ accounted for $60 \%$ and $56 \%$ variations in root and shoot yields respectively. The effects of both temperature and rainfall appeared to be masked by that of RH. This is possible because both rainfall and temperature interact to influence $\mathrm{RH}$. Thus, the combined influence of the three elements appeared to be explained by the RH. This is also reflected by the minimal variation in $\mathrm{RH}(\approx 2 \%)$ over the period resulting to consistent influence (Table 3 ). The analysis of the three climatic elements from the same station over 40 years by Uguru et al. (2011) also showed that the RH was the most stable element but over past five years (20052010), average values of the three elements had been on the increase. From Table 3 the trends in their variations were the same for both during the study period and for the long term averages even though that of rainfall was lower while that of the RH was higher. The RH which influenced the cassava yields most was even more stable during the study period. The greater yields of shoot than root $\left(12.1 \mathrm{vs} 8.5 \mathrm{t} \mathrm{ha}^{-1}\right)$ shows that with reduced rainfall, increases in $\mathrm{RH}$ and possibly stable temperature, cassava grown soley or in mixtures is likely to produce more shoot than root. This will be more beneficial where cassava leaves are consumed as vegetables.

Table 3. Long term averages of the three climatic elements compared with those during study and the cassava yields

\begin{tabular}{|c|c|c|c|}
\hline Climatic element/cassava yields & Mean & Standard deviation & $\begin{array}{l}\text { Coefficient of variation } \\
(\%)\end{array}$ \\
\hline \multicolumn{4}{|l|}{ Long term averages } \\
\hline Rainfall (mm) & 1529 & 246.5 & 16.1 \\
\hline Temperature & 30.1 & 0.5 & 6.7 \\
\hline Relative humidity & 68.3 & 2.5 & 3.6 \\
\hline \multicolumn{4}{|l|}{ Averages during study } \\
\hline Rainfall (mm) & 1462.4 & 170.7 & 11.7 \\
\hline Temperature & 30.02 & 0.27 & 9.0 \\
\hline Relative humidity & 70.72 & 1.6 & 2.3 \\
\hline \multicolumn{4}{|l|}{ Cassava overall mean yields } \\
\hline $\operatorname{Root}\left(\mathrm{t} \mathrm{ha}^{-1}\right)$ & 8.5 & 5.25 & 61.5 \\
\hline Shoot $\left(\mathrm{t} \mathrm{ha}^{-1}\right)$ & 12.06 & 6.89 & 56.9 \\
\hline
\end{tabular}

Source of Long term means (Asadu , 2002) 
Table 4: Mean interaction effects cropping systems by year by location on root and hoot yields of cassava in eastern Nigeria

\begin{tabular}{|c|c|c|}
\hline Cropping system $x$ year $x$ location & Root yield (t ha ${ }^{-1}$ ) & Shoot yield $\left(\mathrm{t} \mathrm{ha}^{-1}\right)$ \\
\hline cassava + maize + pigeon pea $\times 1999 \times$ forest location & 15.4 & 16.8 \\
\hline cassava + maize + pigeon peax $2000 \times$ forest location & 8.1 & 19.7 \\
\hline cassava + maize + pigeon peax $2001 \times$ forest location & 10.6 & 11.4 \\
\hline cassava + maize + pigeon peax $2002 \times$ forest location & 6.8 & 8.1 \\
\hline cassava + maize + pigeon peax $2003 \times$ forest location & 7.8 & 6.1 \\
\hline cassava + pigeon pea $\times 1999 \times$ forest location & 13.2 & 34.7 \\
\hline cassava + pigeon peax $2000 \times$ forest location & 10.5 & 34.9 \\
\hline cassava + pigeon peax $2001 \times$ forest location & 10.6 & 12.7 \\
\hline cassava + pigeon peax $2002 \times$ forest location & 8.0 & 8.4 \\
\hline cassava + pigeon peax $2003 \times$ forest location & 11.6 & 14.9 \\
\hline cassava sole $\mathrm{x} 1999 \mathrm{x}$ forest location & 14.4 & 44.6 \\
\hline cassava solex $2000 \times$ forest location & 5.7 & 26.1 \\
\hline cassava solex $2001 \times$ forest location & 10.6 & 15.5 \\
\hline cassava solex $2002 \times$ forest location & 10.8 & 8.1 \\
\hline cassava solex $2003 \times$ forest location & 11.6 & 17.5 \\
\hline cassava + maize + pigeon pea $x 1999 \times$ UNN location & 13.3 & 14.2 \\
\hline cassava + maize + pigeon peax $2000 \times \mathrm{UNN}$ location & 2.3 & 1.8 \\
\hline cassava + maize + pigeon peax $2001 \times$ UNN location & 2.7 & 1.9 \\
\hline cassava + maize + pigeon peax $2002 \times \mathrm{UNN}$ location & 2.9 & 1.7 \\
\hline cassava + maize + pigeon peax $2003 \times$ UNN location & 3.0 & 2.1 \\
\hline cassava + pigeon pea $\times 1999 \times \mathrm{UNN}$ location & 10.8 & 5.6 \\
\hline cassava + pigeon peax $2000 \times \mathrm{UNN}$ location & 2.3 & 1.4 \\
\hline cassava + pigeon peax $2001 \times$ UNN location & 2.2 & 1.3 \\
\hline cassava + pigeon peax $2002 \times \mathrm{UNN}$ location & 2.5 & 1.5 \\
\hline cassava + pigeon peax $2003 \times$ UNN location & 3.8 & 2.9 \\
\hline cassava sole $\times 1999 \times$ UNN location & 10.3 & 4.9 \\
\hline cassava solex $2000 \times$ UNN location & 3.4 & 1.6 \\
\hline cassava solex $2001 \times$ UNN location & 3.2 & 1.8 \\
\hline cassava solex $2002 \times$ UNN location & 3.6 & 2.3 \\
\hline Cassava solex $2003 \times$ UNN location & 3.4 & 3.1 \\
\hline $\operatorname{LSD}(0,05)$ & 3.4 & 7.4 \\
\hline
\end{tabular}

Table 4 shows that for each year and for each cropping system in two of the locations, the highest root yields $\left(\approx 15 \mathrm{t} \mathrm{ha}^{-1}\right)$ was obtained from the forest location in 1999, that is, $\mathrm{C}+\mathrm{M}+$ $\mathrm{P}$ plots while the least value $\left(2.2 \mathrm{t} \mathrm{ha}^{-1}\right)$ was from the UNN location in 2001.

However, unlike the trend in Table 2 where the minimum shoot and root yields were from different treatments, the minimum shoot yield $\left(\approx 0.7 \mathrm{t} \mathrm{ha}^{-1}\right)$ was also obtained from $\mathrm{C}+\mathrm{P}$ plots at the UNN farm in 2001(Fig. 1).

Earlier work (Asadu et al., 2002) showed that the soils of UNN location were generally less fertile than those of the forest location. Thus, the higher the fertility status the more the vegetative growth in cassava especially where the climatic requirements have been met. Throughout the five years the average of the three climatic elements met the requirement of the test crops (Asadu, 1982). This implies that stability in RH is important in cassava optimum yield and since both rainfall and temperature influence it, manipulation of the three should be considered in getting the best cassava variety that would fit into the changing global climate.

\section{CONCLUSION}

A study carried out in two locations in eastern Nigeria to relate the performance of cassava in three cropping systems with changes in rainfall, temperature and relative humidity over five years showed that the yields were significantly $(p \leq 0.05)$ affected by location, year, and the cropping systems. Out of the three climatic variables the relative humidity accounted for about $60 \%$ variation in cassava root yield and $56 \%$ in shoot yield. The highest average root yield $\left(\approx 15 \mathrm{t} \mathrm{ha}^{-1}\right)$ came from cassava+ maize + pigeon pea plots and the least $\left(\approx 2.2 \mathrm{tha}^{-1}\right)$ from cassava + pigeon pea plots. Thus, cassava+ maize + pigeon pea mixture was considered the most adapted to the variations in rainfall, temperature and relative humidity experienced in the area. 


\section{REFERENCE}

Alliance of Scientists, 2012. IRRIN News, http://www.irrinnews.org/

Andrew, D.J. 1972. Intercropping with sorghum in Nigeria. Expl Agriculture. 13: 139150

Asadu, C.L.A. 1982. Soils in relation to their underlying geological materials in the derived savanna zone (Soil Sci) Thesis. of Anambra state, Nigeria. B.Agric University of Nigeria, Nsukka. Pp 136

Asadu, C.L.A. 1997. The optimum time of yammound remoulding for cassava introduction in yam fields in eastern Nigreia. Tropical Agriculture (Trinidad) 74(4):308-312

Asadu C.L.A 2002 . Fluctuations in the characteristics of an important short tropical season, 'august break' in eastern Nigeria. Discovery and Innovation. 14 (1\&2): 92-101.

Asadu, C. L. A., A. G. O. Dixon and R. Okechukwu. 2002. Comparative evaluation of the contribution of soil physicochemical properties to variations in the yield of four major staple food crops in eastern Nigeria. Soil and Tillage Research 65: 141 155.

Asadu C.L.A ., O.B. Ogbobe and R. Asiedu. 2008Storage life of eleven cultivars of white yam (Dioscorea rotundata) grown with or without NPK fertilizer and the relationship with residual soil NPK. Agro-Science 7 : 235-241.

Food and Agriculture Organization (FAO), 20008.Contact. ttp://www.fao.org/askfao/home.do?

Howeler, R. 1996. Mineral nutrition in cassava, in:Mineral Nutrient Disorders of Root
Crops in the Pacific (eds Cranwell, E.T., Asher, C.J. and O'Sullivan, J.N.), Proceesdings of the Workshop on Mineral Disorders in Root Crops, 17-20 April 1995, Nukualofa, Kingdom of Tonga, pp 110116.

IITA, 1984. Maize plant "architecture", important factor in intercropping with cassava, in: Farming Systems Programme Research Highlights 19811984, International Institute of Tropical Agriculture, Ibadan, Nigeria Kantor, S. 1999. Intercropping, Agricultural and Natural Resources Fact Sheet \# 531.

Washington State University, Cooperative Extension King Country, USA., pp 12.

Majchrzak, R.N., K.R. Olson, G. Bollero, and E.D. Nafziger. 2001. Using soil properties to predict wheat yields in Illinois soils, Soil Sci. 166: 267-280.

Nweke, F.I.,D.S.C. Spenser, and J.K. Lynam. 2002. The cassava transformation: Africa's best- kept secret. Michigan State University Press, USA. Pp273.

Okorji, E. C. 1986. Productivity of yam under alternative cropping systems adopted by small-holder farmers of southeastern Nigeria, Agric. Syst. 22: 231-241.

SAS (Statistical Analysis System). 1985. SAS User's Guide: Statistics, Version. Statistical Analysis System Institute. Cary, N. C.

Uguru, M.I., K.P. Bayeri and S.C. Aba. 2011. Indicators of climate change in the derived savannah niche of Nsukka, . Agro-Science south-eastern Nigeria 10:17-26. 